\title{
Surf Scoter Records
}

By Fred W. Lahrman, Saskatchewan Museum of Natural History

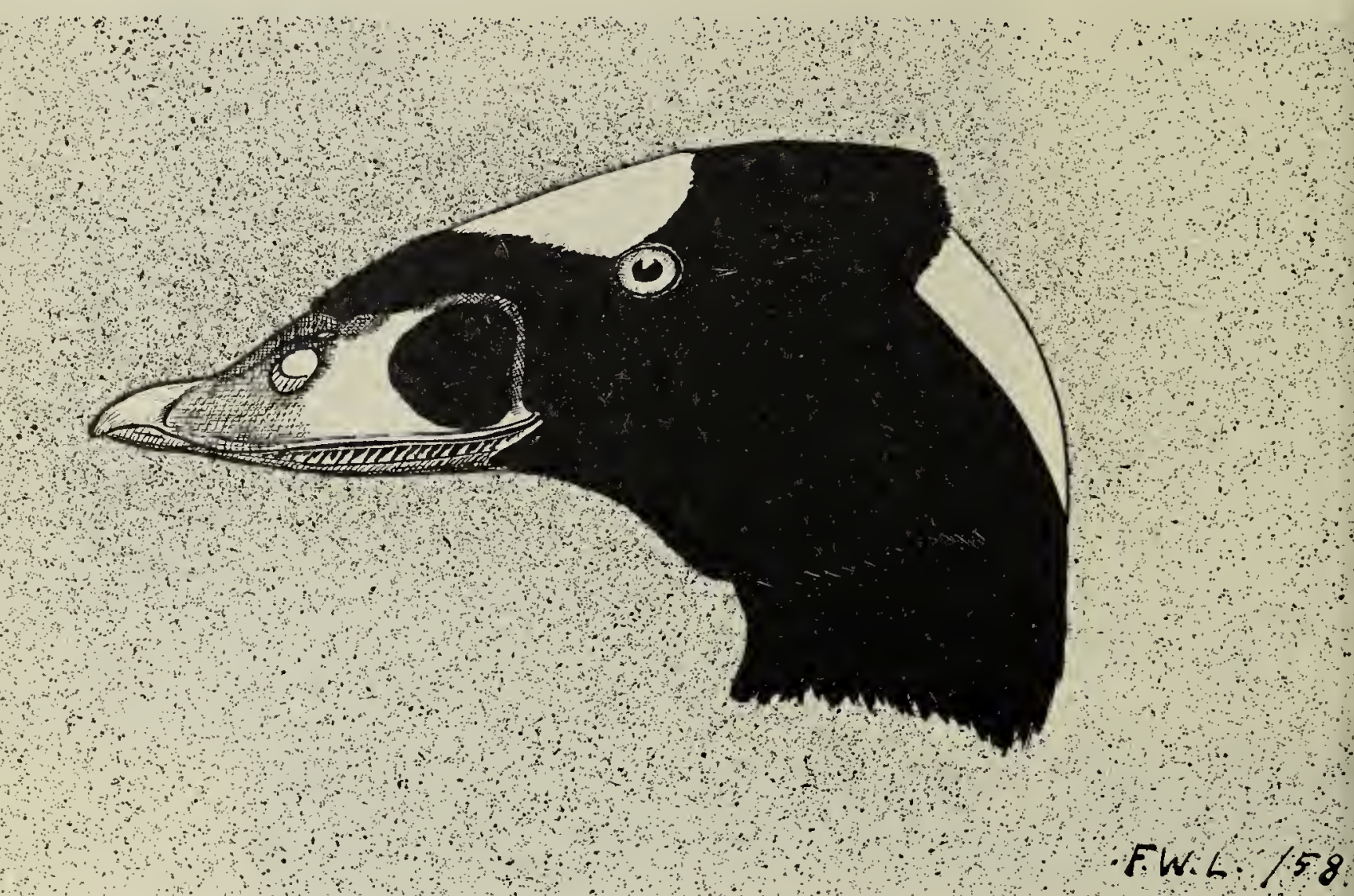

On November 13, 1957 the Saskatchewan Museum of Natural History received a beautiful specimen of a bird which is very rarely seen on our prairies-a Surf Scoter (Melanitta perspicillata.)

This Scoter, an adult male, was received from $\mathrm{Mr}$. Les $\mathrm{M}$ cKenzie of Moose Jaw. It was found frozen in the ice after the storm of November 10-12, 1957, south of Regina near the junction of Nos. 1 and 6 highways, by $\mathrm{Mr}$. Herbert Stouer of Wadena. It was alive when found but died soon after.

While the bird was being prepared as a study skin for the Museum collection, it was discovered that it had been badly injured sometime during the past. The keel or breast bone had been shattered, apparently by shot pellets, and had healed completely in the odd shape shown in the accompanying photo. A No. 4 shotgun pellet was also found lodged in the gizzard, encased in a tough skin covering indicating an old wound. This is an interesting example of the recuperative powers of a bird in the wild.

The Museum has one other Surf Scoter specimen, another male which was taken at Lake Ile a la Crosse,
May 31, 1914 by A. Buchanan.

Apparently, other records of the Surf Scoter in the province are few. H. Hedley Mitchell. 1924, Catalogue of the Birds of Saskatchewan states ". . found breeding at Lake Athabasca, downy young taken August 19 1920 by U.S. Biological Survey Party."

A sight record of a Surf Scoter at York Lake, Yorkton, by Romald anc Donald Hooper, on October 26th, 195: is recorded in the Blue Jay (Vol. 11 No. 4, p.9). I observed an immature male Surf Scoter on the Wascanc Marsh (which is now in the Regine Waterfowl Park) on November 12 1950, and Lucy Murray reports hav. ing seen one on Wascana Lake, Reg. ina, October 17, 1957.

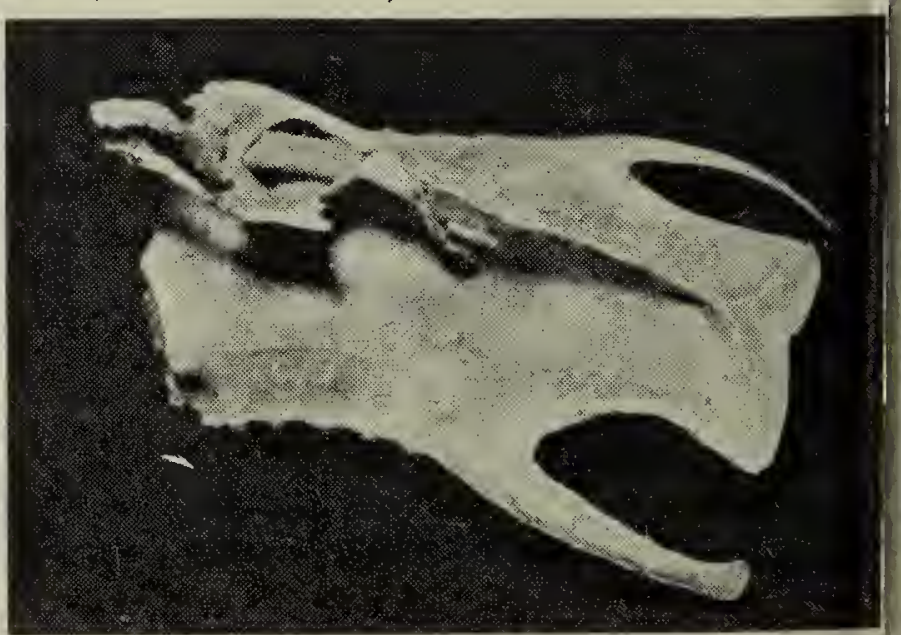

